\section{Early Man in the Somme Valley, France}

A sceptrcism similar to that to which Mr. J. Reid Moir referred in his recent Huxley Memorial Lecture in reviewing the evidence for the existence of man in Pliocene times, has appeared among French archæologists, in attacks on the authenticity of the evidence which would associate the Abbevillian industry, formerly known as pre-Chellean, with an early type of mammalian fauna with Pliocene affinities in the Somme valley. The evidence is derived from the observations of Ault du Mesnil on a quaternary site at Porte du Bois, Abbeville, between 1875 and 1896. $\mathrm{He}$ recorded the association there in the lower horizons of implements with a fauna, which included relics of Elephas meridionalis. This site was further investigated by Commont from 1906 onward; but although he confirmed the existence of a fauna such as Ault du Mesnil had described, with the addition of two early types of rhinoceros, no implements were found in association. In view of this, doubt has been cast on Ault du Mesnil's testimony. It is said that he was misled as to an association, of which, in default of a categorical statement, it is assumed that he had no direct and personal ocular evidence. It is well known that early investigators, including Boucher de Perthes, suffered much from fraud on the part of workmen. The whole matter is thoroughly discussed by the Abbé Breuil in the current issue of L'Anthropologie (49, 1-2; 1939), where he shows that not only was Ault du Mesnil too careful an observer to make a statement for which he had not good ground, but also that the records of the finds occur in unpublished memoranda still extant, though many of his notes have been destroyed. Further, a closely reasoned archæological argument by Breuil supports the authenticity of the evidence, as well as shows the impossibility that such implements as these could have been introduced from another source to be foisted on Ault du Mesnil by fraud. Further argument is rendered unnecessary by the discovery, after this paper was written, by Breuil, accompanied by the chief critic, of implements in the strata in which their existence is in dispute.

\section{Climatic Conditions and Living Things in 1938}

THE spring of 1938 was remarkable in Britain for a long dry period with varied temperature. January and the first ten days of February were warm, following a December with a temperature about $2 \cdot 5^{\circ} \mathrm{F}$. below normal; but a colder spell in late February was succeeded by a March which broke all records in a warm spell, accompanied by drought, which extended into April. The dry spell continued into April and May, but then it was associated by coolness during the day and frosts at night (Phenological Report, 1938, in Quart. J. Roy. Meteor. Soc., 65, 1939). These conditions had a marked effect upon vegetation. At most of the recording stations plant life was brought forward with a rush, so that by the end of March early stations were recording a precedence of 20 days, while at the highest station, Braemar in Aberdeenshire (1100 feet), rather more than 20 days advance was noted. This precocity, restrained to some extent by the drought, was eventually checked by the weather of April and May, which caused widespread damage to blossom and foliage. Insects made an early response, as plants did, and suffered the same check, the recorders sharing an impression that, over all, butterflies and moths were scarce throughout the season.

Migrating birds can scarcely be expected to regulate their coming by conditions at the end of their journey, but although they arrived in season or even earlier than usual in the southern areas, this earliness was reduced, disappeared or was changed to lateness by the time they had reached their northern quarters in April-May. The report makes reference to the profound effect over an extensive area of the invasion of the Norfolk Broads by the sea, which destroyed the freshwater fishes and many other creatures, but the total results of which have not yet been assessed. The Phenological Report is not an easy document to read or understand, owing largely to the mass of statistics which it summarizes and the system of symbols used in the discussion, but it is of great interest, and its band of recorders now numbers 446. Additional observers would add to the trustworthiness of the conclusions, especially in certain areas where records are sparse; for example, no insect observation is listed from Scotland. Any qualified reader of NATURE may obtain the forms necessary for contributing to this team work by applying to the Secretary of the Royal Meteorological Society, 49 Cromwell Road, London, S.W.7.

\section{The Science Museum}

THE report of the advisory council of the Science Museum to the President of the Board of Education for the year 1938 opens on rather an ominous note, for it appears that the suggestion has been made that to provide the badly needed further accommodation a building should be erected with "four or more floors". Miniature skyscrapers may be quite suitable for offices and flats, but there will be very general agreement with the opinion that it is unwise to erect a museum with several storeys. "The Council," says the report, "deem it right to mention that the site area they request for the Science Museum in the future falls short of the areas now occupied by our other major national museums." As the Science Museum represents the very activities on which our national prosperity depends most, it surely is against the country's interest to fetter it by unnecessarily limiting its possibility of serving wide educational purposes, and we trust the views of the Advisory Council will prevail. The various sections of the Museum hitherto known as 'Divisions' are now named 'Departments'. Of these there are now five, namely, the Department of Physics and Geophysics, the Department of Astronomy, Mathematics, Optics and Chemistry, the Department of Civil and Mechanical Engineering and Land Transport, the Department of Industrial Engineering, and the Department of Air and Water Transport. These various titles at once suggest the names of great 